\title{
Human rhinovirus infection of human bronchial epithelial cells results in migration of human airway smooth muscle cells
}

\author{
Sami Shariff*, Sergei Nikitenko, Abid Qureshi, Jason Arnason, Chris Shelfoon, Suzanne Traves, David Proud, \\ Richard Leigh
}

From Canadian Society of Allergy and Clinical Immunology Annual Scientific Meeting 2013

Toronto, Canada. 3-6 October 2013

\section{Background}

Young children who experience human rhinovirus (HRV)-associated wheezing illnesses are more likely to develop subsequent asthma [1]. This has led to the hypothesis that HRV infection may be involved in the pathogenesis of airway remodeling in asthma [2]. Increased airway smooth muscle (ASM) mass, in which ASM cells are in close proximity to the subepithelial region, is a characteristic feature of airway remodeling [3]. We have shown that HRV infection of human bronchial epithelial (HBE) cells, both in vitro and in vivo, results in the upregulation of airway remodeling mediators [4]. We now sought to determine whether HRV infection of HBE cells is associated with airway smooth muscle (ASM) chemotaxis.

\section{Methods}

Primary HBE cells pre-treated with medium containing $1 \%$ insulin, transferrin, and selenium (ITS) for 24 hours were exposed to medium (control) or purified HRV-16 (MOI: 0.3-1) for 24 hours. HBE cell supernatants were then studied as chemoattractants for ASM chemotaxis. ASM migration was examined using both a 48 -well modified Boyden chamber and a 16-well xCELLigence ${ }^{\circledR}$ apparatus (Roche, Laval, Canada). In the latter case, migration to HBE supernatants was measured via electrical impedance, as per manufacturer's instructions, and compared to medium control. Chemotactic gradient was abolished by addition of chemoattractants to top and bottom wells of the apparatuses. Additionally, the effects

\footnotetext{
* Correspondence: sami.shariff@gmail.com

Snyder Institute for Chronic Diseases, University of Calgary, Calgary, Alberta,
} T2N 4N1, Canada

of filtered supernatants and pre-treatment with Pertussis toxin (PTX) on ASM chemotaxis were studied using the xCELLigence ${ }^{\circledR}$ apparatus.

\section{Results}

Supernatants from HRV-16 infected HBE cells resulted in significantly greater ASM cell directional migration, compared to supernatants from HBE cells exposed to medium (negative control) in both the Boyden chamber $(\mathrm{n}=3 ; \mathrm{p}<0.01)$ and the $\mathrm{xCELLigence} \mathrm{system}(\mathrm{n}=3$; $\mathrm{p}<0.001)$; relationship was concentration-dependent $(\mathrm{n}=3 ; \mathrm{p}<0.05)$. Time course experiments demonstrated that rate of migration was maximal at 4 hours. Migration was significantly attenuated when the chemotactic gradient was abolished, indicating that directional cell migration is due to chemotaxis and not chemokinesis $(\mathrm{n}=3 ; \mathrm{p}<0.001)$. ASM migration significantly increased even after filtration of HRV and proteins greater than $100,000 \mathrm{MW}(\mathrm{n}=3 ; \mathrm{p}<0.05)$. However, pretreatment with PTX abrogated HRV-induced ASM chemotaxis $(n=3$, $\mathrm{p}<0.05)$. Pretreatment with dexamethasone, formoterol, or combination, abolished ASM chemotaxis $(n=4$, $\mathrm{p}<0.05)$.

\section{Conclusions}

These data provide the first demonstration that HRV infection of airway epithelial cells produces soluble factor(s) that cause directional migration of ASM cells. Moreover, migration appears to be dependent on a PTX sensitive pathway. Taken together, they provide further evidence for a role of HRV infection in the pathogenesis of airway remodeling in asthma. 


\section{Acknowledgements}

This abstract was funded in part thanks to AllerGen NCE., the Queen

Elizabeth II scholarship, Canadian Institutes of Health Research, and GSK-CIHR

Professorship in inflammatory lung disease.

Published: 3 March 2014

\section{References}

1. Lemanske RF: The childhood origins of asthma (COAST) study. Pediatr Allergy Immunol 2002, 13:38-43.

2. Proud D, Leigh R: Epithelial cells and airway diseases. Immunological reviews 2011, 242:186-204.

3. Gerthoffer WT: Migration of airway smooth muscle cells. Proc Am Thorac Soc 2008, 5:97-105.

4. Leigh $R$, et al: Human rhinovirus infection enhances airway epithelial cell production of growth factors involved in airway remodeling. J Allergy Clin Immunol 2008, 121:1238-1245.e4.

doi:10.1186/1710-1492-10-S1-A69

Cite this article as: Shariff et al: Human rhinovirus infection of human bronchial epithelial cells results in migration of human airway smooth muscle cells. Allergy, Asthma \& Clinical Immunology 2014 10(Suppl 1):A69.

\section{Submit your next manuscript to BioMed Central} and take full advantage of:

- Convenient online submission

- Thorough peer review

- No space constraints or color figure charges

- Immediate publication on acceptance

- Inclusion in PubMed, CAS, Scopus and Google Scholar

- Research which is freely available for redistribution

Submit your manuscript at www.biomedcentral.com/submit 